\title{
A futurológus előre megmondta
}

Alvin Toffler: A harmadik hullám

Így hivatkozzon erre a cikkre:

Kömlődi Ferenc. „A futurológus előre megmondta”.

A folyóiratban közölt müvek

a Creative Commons Nevezd meg! - Ne add el! - Így add tovább! 4.0 


\title{
A futurológus előre megmondta
}

\author{
Alvin Toffler: A harmadik hullám
}

Végre magyarul is olvasható a neves amerikai futurológus és társadalomtudós, Alvin Toffler 1980-as, mindmáig aktuális, nagyhatású kulcsműve, A harmadik hullám. A szerzô más jelentős munkái (például a Jövősokk) még mindig fordításra várnak. Pedig, ellentétben Tofflerével, a múltban felvázolt jövóképek túlnyomó többsége manapság ugyancsak mosolyt fakaszt, vagy - mosoly nélkül - egyszerűen nem vált valóra. A múlt futurológusai általában vicces álmodozóknak tűnnek, jókat derülünk rajtuk, mint amikor a Filmmúzeum csatornáján elkapjuk a „Halló fiúk, halló lányok” egyik 1968-as adását, amelyben Antal Imre fehér múszálas garbóban faggat ưrkutatókat, hogy hogyan fogunk tubusból étkezni a Holdon kétezerben.

\section{A jövő egészen másmilyen let†}

Lehet sorolni a valóra nem vált jóslatokat: az űrkutatás messze nem váltotta be a hatvanas évek végén hozzáfüzött reményeket, nagyon távol vagyunk még a Marstól, a tömeges ûrrepülésnek nyoma sincs, sốt! A számítógépek, illetve a mesterséges intelligencia, a robottechnológia fejlôdési irányait is egészen másfelé sejtették negyven évvel ezelőttt, de még húsz éve is. Beszélő gépekről, mesterséges értelemrôl, robotinasokról sokan álmodoztak, a kommunikáció, a mikroelektronikai forradalom valós lehetôségeit viszont nem sejtették meg.

Toffler elkerülte a csapdákat: nem bocsátkozott konkrét jóslatokba, hanem tendenciákat, irányokat, és egy mindent átalakító, globális méretû váltást vetített elốre. Mindezt élvezetes, rendkívül szórakoztató, tudományos szôrszálhasogatásoktól, posztmodern okoskodásoktól mentes stílusban. A múltból kiindulva, plasztikus képekben felvillantva a régi civilizációt, logikusan „építi fel” a jövő társadalmát, s annak bonyolult - információ-alapú - kapcsolatrendszerét, az „új szintézist”, a „XXI. század demokráciáját”. A „tudományos-technikai forradalom szülte „technotronikus”, „posztindusztriális”, „szuperindusztriális” társadalmat.

„Ez az új civilizáció olyan mélységesen forradalmi, hogy valamennyi régi beidegződésünket megkérdôjelezi” - írja. A jelen, 2002: valamennyien Toffler „harmadik hullámának" megvalósulását éljük át, az 1982 óta eltelt évek ôt igazolták.

Toffler sohasem tetszelegett próféta-pózban. „Amikor azt mondom, hogy valami meg fog történni, feltételezem, hogy az olvasó ebbe beleérti a megfelelő bizonytalansági tényezôt" - fejti ki az előszóban. 


\section{Szubjektív valóság? És mit értünk hullámokon?}

„A társadalmi előrejelzések sohasem értékmentesek vagy tudományosak, tekintet nélkül arra, hogy mekkora számítógépes adatbázist használnak. A harmadik hullám nem objektív elôrejelzés, és nem kívánja azt a látszatot kelteni, hogy mondanivalója tudományosan bizonyított lenne.” És mégis, sokkal inkább megvalósulni látszanak a könyvben leírtak, mint a magukat általában tudományosan tárgyszerúnek feltüntetố jövőjós agymenések.

A könyv központi metaforája a „változás egymással ütközô hullámainak képe”. Az emberiség történetében eddig két, a korábbi valóságot alapjaiban megrázó, átalakító hullámról beszélhetünk: a gyưjtögető életformát felszámoló mezőgazdaság, illetve a mezôgazdaságot váltó ipar térnyerésérôl. Az ipar által megszemélyesített „második hullámot” váltja az információ jelképezte, nyíltabb társadalmakat „ígéró” harmadik, mely ékes bizonyosságát adja, hogy „az emberiség története, nemhogy a végét járná, hanem inkább még csak most kezdődött el igazán”.

Egy teljesen új civilizáció készül: új családmodellel, megváltozott munkamódszerekkel, új életmóddal, másféle szerelemmel, új gazdasággal (!) és politikai-társadalmi konfliktusokkal, másféle gondolkodásmóddal. A harmadik hullám múlt idóbe teszi az ipari társadalmak szabályrendszerét („mintáit”): standardizációt, specializációt, szinkronizációt, koncentrációt, maximalizációt és centralizációt. Felszámolja a mezôgazdaság térvesztésével beállt termelés és fogyasztás közötti elidegenedést, ellentétet.

A hagyományos nemzetállamoknak szintén véget vet: Toffler - McLuhan-re emlékeztetve - „globális vállalatról”, „planetáris tudatról” és transznacionális szervezetekrốl („t-háló”) elmélkedik. És így tovább... Azaz, a mát, 2002-t és a közeljövốt vázolta fel... Vagy, mint ahogy Z. Karvalics László írja a bevezetôben: „az információs korszak kutatói mindnyájan Toffler trilógiájának köpönyegéből bújtak elő.”

Kömlödi Ferenc

\section{IRODALOM}

Alvin Toffler: A harmadik hullám (The Third Wave); 2001 Budapest, Typotex kiadó, Információs társadalom A-tól Z-ig sorozat; fordította: Rohonyi András 